\title{
Responses of thallus anatomy and chlorophyll fluorescence-based photosynthetic characteristics of two Antarctic species of genus Usnea to low temperature
}

\author{
J. HÁJEK (iD), A. HOJDOVÁ, K. TRNKOVÁ, P. VÁCZI (D) , M. BEDNAŘíKOVÁ, \\ and M. BARTÁK ${ }^{+}$D
}

Department of Experimental Biology, Laboratory of Photosynthetic Processes, Faculty of Science, Masaryk University, Kamenice 5, 62500 Brno, Czech Republic

\begin{abstract}
Biometrical parameters of two fruticose lichens from Antarctica (Usnea aurantiaco-atra, U. sphacelata) were studied using thallus cross-sections at basal, middle, and apical parts of thallus. The thallus diameter (TD), the thickness of the upper cortex (UCT), distribution of symbiotic alga (Trebouxia sp.) in the algal layer, the thickness of medulla (MT), central cord diameter, and area (CCD, CCA) were measured. U. sphacelata had comparable relative UCT $(0.080-0.110$, relative to diameter) to U. aurantiaco-atra $(0.085-0.130)$. The relative MT was higher in U. sphacelata $(0.240-0.300)$ than $U$. aurantiaco-atra $(0.080-0.180)$. In $U$. aurantiaco-atra, the CCA was two times larger than that in U. sphacelata. Rapid freezing of thalli in liquid nitrogen led to an increase in TD, UCT, CCD because of intrathalline ice crystals formation. Cultivation of symbiotic alga at different temperatures $(1.5,6.0,15.0,22.0$, and $28.0^{\circ} \mathrm{C}$ ) with repetitive chlorophyll fluorescence parameters measurements showed growth optimum of $15.0^{\circ} \mathrm{C}$ for potential and effective quantum yield.
\end{abstract}

Keywords: cross-sections; lichen; temperature effects; Usnea aurantiaco-atra; Usnea sphacelata.

\section{Introduction}

The genus Usnea has large inter and intraspecific variability in anatomy and morphology (Randlane et al. 2009). This genus is most diverse in temperate and tropical forests, particularly in montane rainforests (see e.g., Truong et al. 2013). However, it is distributed and abundant in many boreal forests as well as in the Southern
Hemisphere including Antarctica (Øvstedal and Lewis Smith 2001). Usnea sphacelata and Usnea aurantiaco-atra are dominant components of Antarctic lichen flora in the South Shetlands archipelago. The two species have been studied both in the field and in a laboratory experiment in order to evaluate the species responses to environmental factors and determine the key factors affecting their growth and morphology. Within the last decade, attention

\section{Highlights}

- Temperature-response curves of $\mathrm{F}_{\mathrm{V}} / \mathrm{F}_{\mathrm{M}}$ and $\Phi_{\mathrm{PSII}}$ are triphasic in the two Usnea species

- Shock freezing of wet lichen thalli leads to an increase in thallus and cord diameter

- Isolated photobiont (Trebouxia) shows optimum of Chl fluorescence parameters at $15^{\circ} \mathrm{C}$
Received 1 July 2020

Accepted 4 January 2021

Published online 12 February 2021

${ }^{+}$Corresponding author

e-mail: mbartak@sci.muni.cz

Abbreviations: CCA - central cord area; $\mathrm{CCD}$ - central cord diameter; $\mathrm{Chl}$ - chlorophyll; $\mathrm{F}_{0}$ - background chlorophyll fluorescence; $\mathrm{F}_{\mathrm{M}}$ - maximum chlorophyll fluorescence reached after the application of a saturation pulse in dark-adapted state; $\mathrm{F}_{\mathrm{P}}-$ peak chlorophyll fluorescence reached after the continuous (actinic) light is switched on; $\mathrm{F}_{\mathrm{V}} / \mathrm{F}_{\mathrm{M}}$ - potential yield of photochemical processes of PSII; MT - thickness of medulla; TD - thallus diameter; UCT - thickness of the upper cortex; $\Phi_{\mathrm{PSII}}$ - effective quantum yield of photochemical processes of PSII.

Acknowledgements: The authors thank the ECOPOLARIS and CzechPolar-I, II projects (CZ.02.1.01/0.0/0.0/16_013/0001708, LM2010009, and LM2015078) for providing facilities and the infrastructure used in the research reported in this study.

Conflict of interest: The authors declare that they have no conflict of interest. 
was devoted to taxonomical problems (Mark et al. 2016), distribution, and ecological requirement (Ruiz-Fernández et al. 2017), in situ monitoring of growth rate (Sancho et al. 2017), and ecophysiology of Usnea sp. (Laguna-Defior et al. 2016). Particular physiological responses to limiting environmental factors, such as resistance to photoinhibition (Balarinová et al. 2014), temperature (Colesie et al. 2018), freezing tolerance (Hájek et al. 2016), and strategies of water uptake, and dehydration resistance (Jonsson Cabrajić et al. 2010), were studied as well. Last but not least, several studies have addressed photosynthetic performance evaluated by gas exchange (Kappen et al. 1995, Cao et al. 2015), chlorophyll (Chl) fluorescence exploiting (1) fast (OJIP) transients (Bednař́ková et al. 2020a,b), (2) slow Kautsky kinetics with quenching analysis (Hájek et al. 2001, 2009) or (3) monitoring of in situ effective quantum yield of PSII (Cho et al. 2020). Some studies combine gas exchange and $\mathrm{Chl}$ fluorescence measurements (e.g., ten Veldhuis et al. 2020).

Ecophysiological characteristics of the two representatives of Antarctic Usneaceae reflect the concept of structure and function. In this respect, understanding of inter and intraspecific variability in thallus morphology is of crucial importance for the evaluation of the behaviour of the species in situ and their potential to cope with ongoing environmental changes in Antarctic terrestrial vegetation oases. It is well established that morphology may alter water storage strategies in representatives of genus Usnea (Eriksson et al. 2018). Such functionrelated morphological approach comprises studies of the branching pattern of thalli, 3-D structure and arrangement of lichen thalli clusters, and variability in morphological characteristics (e.g., soralia, or papillae; for details, see below). These studies are rather rare and there is still a substantial gap in knowledge regarding the morphometric parameters in Antarctic Usenaceae.

Seymour et al. (2007) focused on morphologies of the principal Antarctic species of genus Usnea. They described the most important interspecific differences between five species ( $U$. antarctica, U. aurantiaco-atra, U. sphacelata, U. subantarctica, and U. trachycarpa). The authors compiled data from Walker (1985) and Øvstedal and Lewis Smith (2001) and classified the following morphological characteristics: presence/absence of soralia, papillae, fibrils, the pattern of thallus pigmentation, apothecia, and apothecia rays. They also paid partial attention to the cross-sections of the thalli and examined diameters of both the central axis and the whole branch and evaluated the relative diameter of the axis (expressed as a percentage of the whole thallus diameter). Morphological differences, however, might be found even within a single species. It has been reported for $U$. auratiaco-atra (Cao et al. 2018) that four morphological subgroups may be distinguished according to the presence/absence and proportion of apothecia to soredia.

In our study, we focused on the detailed biometrical analysis of the components forming cross-sections in two Usnea species: Usnea aurantiaco-atra and U. sphacelata. We also addressed the question of whether the proportion of individual structural components (upper cortex, medulla, and cord) to cross-section diameter have similar numerical value when evaluated for the basal, middle, and upper parts of individual branches. We hypothesized that the size of structural components of thallus might be changed and injured after fast freezing episodes happening to wet thalli in the field. To evaluate freezing-induced changes of the two Usnea species, we used a rapid freezing approach (see e.g., Orekhova et al. 2018) which focuses on anatomical properties and physiological processes in cells surviving a short-term immersion of wet lichen thalli to liquid nitrogen. Moreover, we addressed intraspecific differences in cryoresistance of the two species. We expected speciesspecific differences in photosynthetic performance (monitored by several Chl fluorescence parameters) in Usnea thalli exposed to a short-term progressive cooling from room temperature to $-25^{\circ} \mathrm{C}$. We also hypothesized that the photosynthetic performance of symbiotic alga would differ even during long-term cultivation at several low temperatures. Therefore, we cultivated isolated algal cells (Trebouxia sp.) in a gradient cultivator and monitored the effective quantum yield of photochemical processes in PSII in order to identify optimum growth temperature and the species-specific differences in the rate of acclimatory changes to low temperature.

\section{Materials and methods}

Lichen samples: Two fruticose lichens of Usnea genus were used for the study of anatomical changes after rapid freezing in liquid nitrogen. Usnea sphacelata samples were collected in February and March 2018. The collection site was located close to the Panorama Pass $\left(63^{\circ} 48^{\prime} 51^{\prime \prime S}\right.$, $57^{\circ} 49^{\prime} 53^{\prime \prime} \mathrm{W}, 242 \mathrm{~m}$ a.s.1.) at James Ross Island, Antarctica. Thalli of $U$. aurantiaco-atra were collected at the La Cruz Plateau in the Fildes Peninsula, King George Island $\left(62^{\circ} 12^{\prime} \mathrm{S}, 58^{\circ} 57^{\prime} \mathrm{W}, 41 \mathrm{~m}\right.$ a.s.1.). For more details of the collection site, see Casanova-Katny et al. (2016). After collection, the thalli were cleansed of substrate and dirt and subsequently dried out naturally (shade and windy place, at the temperature of 2 to $5^{\circ} \mathrm{C}$ ), stored in a dry state in a refrigerator (at the temperature of $5^{\circ} \mathrm{C}$ for two weeks), and then transported to the Czech Republic.

Cross-sections and microscopy: In the laboratory at Masaryk University, Brno, the thalli were stored in a dry state for two months in a refrigerator at $5^{\circ} \mathrm{C}$. Before experiments, the thalli were put in between two wet papers and rehydrated for $24 \mathrm{~h}$ at $5^{\circ} \mathrm{C}$ and under dim light [10 $\mu$ mol(photon) $\mathrm{m}^{-2} \mathrm{~s}^{-1}$. Cross-sections were then prepared by razor blade on rubber pad in saturated state of lichen thallus. The cross-sections of thalli were made in different parts of thallus: nearly to the base, in the middle of the thallus (before first branching), bellow the top of the thallus (before the last branching). For preparing the crosssections, $5 \%$ of the whole thallus length was used for basal cross-sections, and the middle part was defined by nearly $50 \%$ of the whole length. The part before the last branching of thallus was used for the top cross-sections. The crosssections from every part were placed on a microscope slide into a drop of distilled water. About 20-30 cross-sections 
suitable for photographing (undamaged, undistorted, without cracks, with the same width in the whole crosssection) were prepared from each part of the thallus (different thalli for each species). Before microscopy and photographing on a digital light microscope, the excess water was soaked by absorbent paper. The cross-sections were observed by digital light microscope KEYENCE VHX-900F (Keyence Corp., Belgium).

Evaluation of anatomical parameters: Evaluated parameters related to the individual layers distinguishable at cross-sections were: (1) the width of the upper cortex, (2) the width of medulla with cells of the photobiont, (3) the width of central cord, and (4) the width of the whole thallus. In the case of distinguishable papillae on a cross-section, the width and length of papillae were measured. The width of the central cord and whole thallus was measured in five replicates, the width of the upper cortex and medulla in 20 replicates in different positions at the cross-section. All pictures were evaluated in graphic VHX-500_900F software ver. 1.7.0.3 (Keyence Corp., Belgium).

Rapid freezing effects on lichen anatomy: Samples of both lichen species were hydrated by distilled water in the Petri dish on/under a wet piece of filter paper until they reached the fully hydrated state. Hydration of thalli lasted $24 \mathrm{~h}$ at a room temperature $\left(23^{\circ} \mathrm{C}\right)$. Whole hydrated thalli were then frozen by immersion in liquid nitrogen $\left(-196^{\circ} \mathrm{C}\right)$ for $5 \mathrm{~min}$. After the freezing procedure, the thalli were naturally thawed at laboratory temperature $\left(23^{\circ} \mathrm{C}\right)$ and moistened with distilled water again. The control treatment was represented by the thalli fully hydrated by distilled water by the same method but not exposed to the freezing in liquid nitrogen. In both groups, i.e., (1) untreated control and (2) rapid frozen and thawed thalli, anatomical characteristics were evaluated by optical microscopy in 20 replicates (cross-sections from five different thalli in each species).

Cultivation of symbiotic alga: For the photobiont growth experiments, we used the stock culture of Trebouxia sp. isolated from thalli of Usnea sphacelata (EEL - Collection of the Extreme Environments Life Laboratory Department of Experimental Biology, Masaryk University). The alga was inoculated on solid Bold basal medium (BBM) solidified with 1.5\% agar and cultivated for six weeks before the experiments. Then it was cultivated in liquid $\mathrm{BBM}$ medium [temperature of $15^{\circ} \mathrm{C}$, the light of $20 \mu \mathrm{mol}$ (photon) $\mathrm{m}^{-2} \mathrm{~s}^{-1}$ ] and used for experiments after reaching sufficient density (tested by digital light microscope).

Evaluation of optimum growth temperature: The algal culture $(10 \mathrm{ml})$ was transferred from the liquid medium onto glass filters (porosity of $0.42 \mu \mathrm{m}$ ) by vacuum filtration to form a homogeneous layer of algal inoculum. Then, the filters with algal cultures were placed in Petri dishes on a solid BBM medium and the algae were allowed to grow for $14 \mathrm{~d}$ in aerophytic conditions $\left[17^{\circ} \mathrm{C}, 35 \mu \mathrm{mol}(\right.$ photon) $\mathrm{m}^{-2} \mathrm{~s}^{-1}$. During the growth, the cultures were checked regularly by Chl fluorescence measurements (FluorCam HFC-010, Photon Systems Instrument). After reaching optimal values of potential primary photosynthesis $\left(\mathrm{F}_{\mathrm{V}} / \mathrm{F}_{\mathrm{M}}>0.6\right.$, for method, see e.g., van Kooten and Snell 1990), the cultures on filters were used for evaluation of the optimum growth temperature. Petri dishes were placed on a temperature gradient cultivator ( $L A B I O$, Prague, Czech Republic) and cultivated at the temperature of 1.5, 6.0, $15.0,22.0$, and $28.0^{\circ} \mathrm{C}$ for $4 \mathrm{~d}$. The cultures were exposed to PAR of $35 \mu$ mol(photon) $\mathrm{m}^{-2} \mathrm{~s}^{-1}$ and $16 / 8 \mathrm{~h}(\mathrm{~L} / \mathrm{D})$ photoperiod. Chl fluorescence parameters were measured every $24 \mathrm{~h}$, exploiting the approach of slow Kautsky kinetics of $\mathrm{Chl}$ fluorescence supplemented with saturation pulses (for method see e.g., Roháček et al. 2008). In order to evaluate the effect of cultivation temperature on primary photosynthetic processes, the following parameters were measured and analysed as dependent on the cultivation time: maximum yield of PSII photochemistry $\left(\mathrm{F}_{\mathrm{V}} / \mathrm{F}_{\mathrm{M}}\right)$, effective quantum yield of PSII photochemistry $\left(\Phi_{\mathrm{PSII}}\right)$, background (minimum) Chl fluorescence $\left(\mathrm{F}_{0}\right)$, peak $\mathrm{Chl}$ fluorescence on light $\left(\mathrm{F}_{\mathrm{P}}\right)$, and maximum $\mathrm{Chl}$ fluorescence induced by saturation light pulse $\left(\mathrm{F}_{\mathrm{M}}\right)$ - for parameters definition and application in lichen studies focused on temperature effects, see e.g., Marečková and Barták (2016).

Chl fluorescence parameters in response to cooling: The culture of $T$. erici was filtered through a filter paper which was placed into the cooling chamber of the KryoPlaner unit (United Kingdom). The chamber was linked to a 20-L Dewar flask with liquid nitrogen and cooled from 20 to $-25^{\circ} \mathrm{C}$ at a constant rate of $2^{\circ} \mathrm{C} \min ^{-1}$. Before cooling, an individual sample was equilibrated to $20^{\circ} \mathrm{C}$ for 15 min. The process of cooling was PC-controlled, and chamber $\left(T_{\text {ch }}\right)$ and sample temperature $\left(T_{s}\right)$ were regularly measured by in-built thermocouples. Simultaneously with cooling, Chl fluorescence parameters $\left(\mathrm{F}_{\mathrm{V}} / \mathrm{F}_{\mathrm{M}}, \Phi_{\mathrm{PSII}}\right)$ were measured on algal culture by a PAM 2000 fluorometer (Walz, Germany). The distance between the probe end and the sample was typically $3 \mathrm{~mm}$ to ensure a satisfactorily high Chl fluorescence signal. Repeated saturation pulses of 5,000 $\mu \mathrm{mol}$ (photon) $\mathrm{m}^{-2} \mathrm{~s}^{-1}(0.8 \mathrm{~s})$ of PAR were applied each $30 \mathrm{~s}$ to induce maximum $\mathrm{Chl}$ fluorescence signals ( $F_{M}$ and $F_{M}$ ' for dark- and light-adapted state, respectively). For $\mathrm{F}_{\mathrm{V}} / \mathrm{F}_{\mathrm{M}}$ determination, the following values were used: background $\left(\mathrm{F}_{0}\right)$ and maximum $\left(\mathrm{F}_{\mathrm{M}}\right)$ measured on darkadapted samples. For $\Phi_{\text {PSII }}$ evaluation, actinic light of $30 \mu \mathrm{mol}$ (photon) $\mathrm{m}^{-2} \mathrm{~s}^{-1}$ provided by a fluorometer was used. It was switched on $5 \mathrm{~min}$ before the cooling protocol started and lasted until the end of the cooling period. Three repeated measurements were conducted for $\mathrm{F}_{\mathrm{V}} / \mathrm{F}_{\mathrm{M}}$ and $\Phi_{\text {PSII. }}$. Means of $F_{V} / F_{M}$ and $\Phi_{\text {PSII }}$ were calculated for a class of $1^{\circ} \mathrm{C}$ and plotted against temperature.

Statistical analysis: For the statistical evaluation, we used factorial analysis of variance $(A N O V A)$ with the software Dell Statistica ver. 13 (Dell Inc., Tulsa, USA). The significant differences between tested variants of biometrical thalli parameters and indices were evaluated 
by Fisher's LSD test at $p=0.05$ after the normality of the data was verified and homogeneity of data variance was confirmed.

\section{Results}

Analysis of biometric parameters derived from crosssections revealed anatomical structures typical for Usneaceae in both species, i.e., thick cortex layer and underlying medulla with irregularly arranged clusters of Trebouxia sp. forming interrupted ring (Figs. 1, 2). In the central part of cross-sections, mechanical pseudo tissue (cord) was found.

The diameter of cross-sections of wet branches showed a relatively large variation among individual thalli in both species (Fig. 3). However, it generally decreased from the base to apex of individual branches, more apparently in $U$. aurantiaco-atra. U. aurantiaco-atra had about two times higher thallus diameter in the basal part of individual branches. The thickness of cortex, medulla, and cord all increased with the branch diameter.

Cells of algal photobiont were found beneath the upper cortex in the outermost part of the medulla. They were irregularly distributed forming clusters of different sizes (typically ranging from 10 to $120 \mu \mathrm{m}$ ). No regular ring of an algal layer was observed in both species, contrastingly

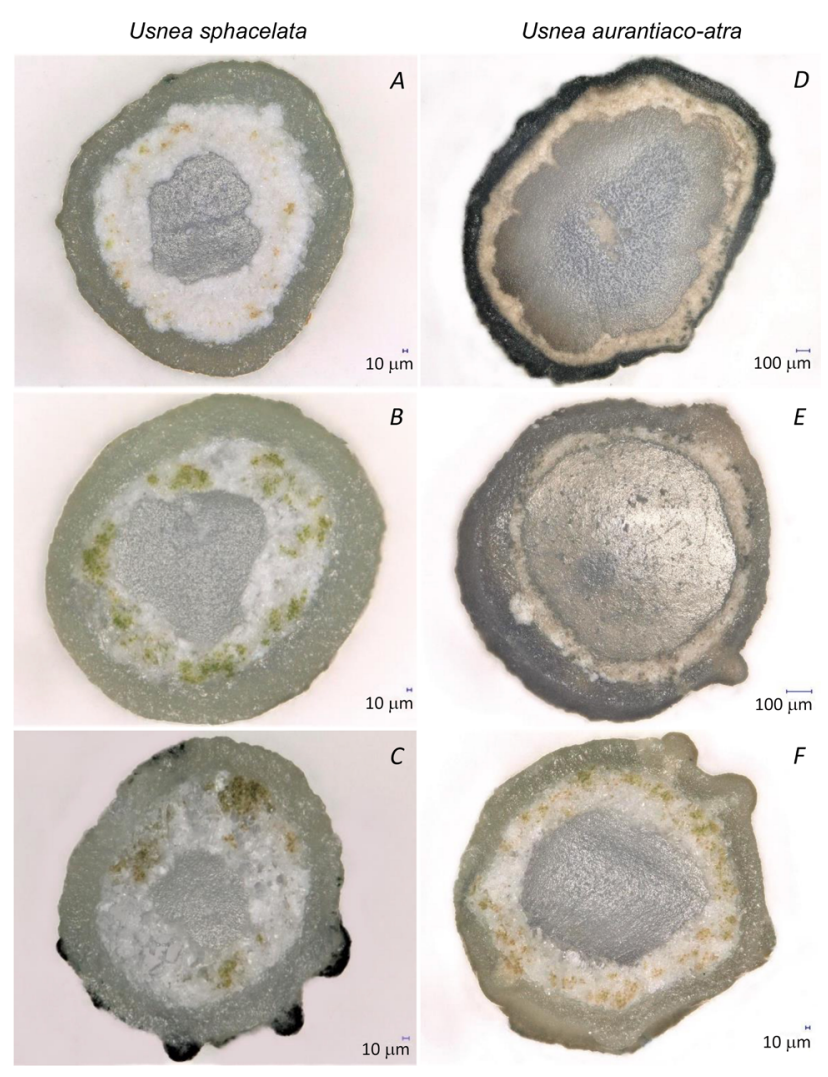

Fig. 1. Typical cross-sections of Usnea sphacelata and Usnea aurantiaco-atra taken in basal $(A, D)$, middle $(B, E)$, and apical parts $(C, F)$ of individual branches of thallus. The photos taken by a Keyence 500 digital microscope and its graphic software. to other species of the genus (e.g., U. flammea, U. subfloridana, U. cornuta - Eriksson 2016).

The relative thickness of the upper cortex and medulla along the radius (see index values in Fig. 4) varied between the two species. U.antarctica had a comparable relative thickness of cortex $(0.080-0.110)$ to $U$. aurantiaco-atra (0.085-0.130). The relative thickness of medulla, however, showed high interspecific differences: 0.240-0.300 (U. sphacelata) and 0.080-0.180 (U. aurantiaco-atra). Relative index for the cord (cord diameter to thallus thickness) was found much lower for U. sphacelata $(0.260$ $0.300)$ than that of $U$. aurantiaco-atra (0.400-0.650). Species-specific differences in central cord diameter were also reflected in the relative cord area (see Fig. 3). In $U$. sphacelata, much lower value $(0.230-0.300)$ was found than that for $U$. aurantiaco-atra $(0.440-0.620)$.

A central cord was formed by thick-walled, agglutinated hyphae. In both species, a single threadlike elastic cord was found. The cord formed a central axis which provides the requisite tensile and skeletal strength to an individual part of a single branch. The filaments forming the central cord were packed and observed as integrated tissue in which no individual cells/cell walls were distinguishable by digital microscopy (Fig. 1).

The cord formed much larger part of overall crosssection in U. aurantiaco-atra than in U. sphacelata (Fig. 1), and reached higher values of cord diameter in basal, middle, and apex parts (Fig. 3). The relative thickness of the upper cortex, medulla, and cord are given as index values (relative to thallus diameter) in Fig. 4. In the majority of cases, they differed between the two species, and before and after shock freezing.

Chl fluorescence parameters in response to cooling: In T. erici, $\mathrm{F}_{\mathrm{V}} / \mathrm{F}_{\mathrm{M}}$ values decreased with decreasing sample temperature forming a triphasic curve (Fig. 5). The three phases were distinguished as follows: an initial linear decrease found at the sample temperature decreasing from 20 to $8^{\circ} \mathrm{C}$ (Phase I), an intermediate phase typical of more or less constant $\mathrm{F}_{\mathrm{V}} / \mathrm{F}_{\mathrm{M}}$ value $(0.32$, decrease from 8 to $-11^{\circ} \mathrm{C}$, Phase II), and the end part of the curve (a decrease to close-to-zero values of $F_{V} / F_{M}$ found at $-25^{\circ} \mathrm{C}$, Phase III). Similar phases were distinguished for $\Phi_{\text {PSII }}$, which decreased rapidly with temperature from 20 to $8^{\circ} \mathrm{C}$ (Phase I). Then, Phase II was typical by a slight decrease of $\Phi_{\text {PSII }}$ from 8 to $-16^{\circ} \mathrm{C}$. Phase III was in the temperature range of -19 to $-25^{\circ} \mathrm{C}$. At $-25^{\circ} \mathrm{C}$, zero of $\Phi_{\text {PSII }}$ was reached. Within the whole range of decreasing temperature, the decline of $\Phi_{\mathrm{PSII}}$ was more rapid and pronounced than $\mathrm{F}_{\mathrm{V}} / \mathrm{F}_{\mathrm{M}}$ (see inset in Fig. 5).

Optimum growth temperature: Chl fluorescence parameters related to primary photosynthetic processes $\left(\mathrm{F}_{\mathrm{V}} / \mathrm{F}_{\mathrm{M}}\right.$, $\left.\Phi_{\text {PSII }}\right)$ of $T$. erici showed an adjustment to cultivation temperature, more pronounced with cultivation time (Fig. 6). After $96 \mathrm{~h}$, the optimum temperature of $15^{\circ} \mathrm{C}$ was found in both species. Higher or lower temperatures led to the limitation of $\mathrm{F}_{\mathrm{V}} / \mathrm{F}_{\mathrm{M}}$ and $\Phi_{\mathrm{PSII}}$. Apart from the two parameters, $\mathrm{Chl}$ fluorescence signals showed temperature dependence. For background $\mathrm{Chl}$ fluorescence $\left(\mathrm{F}_{0}\right)$, an 


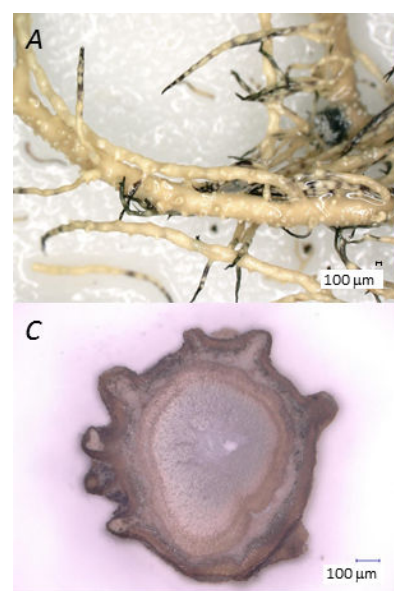

$E$
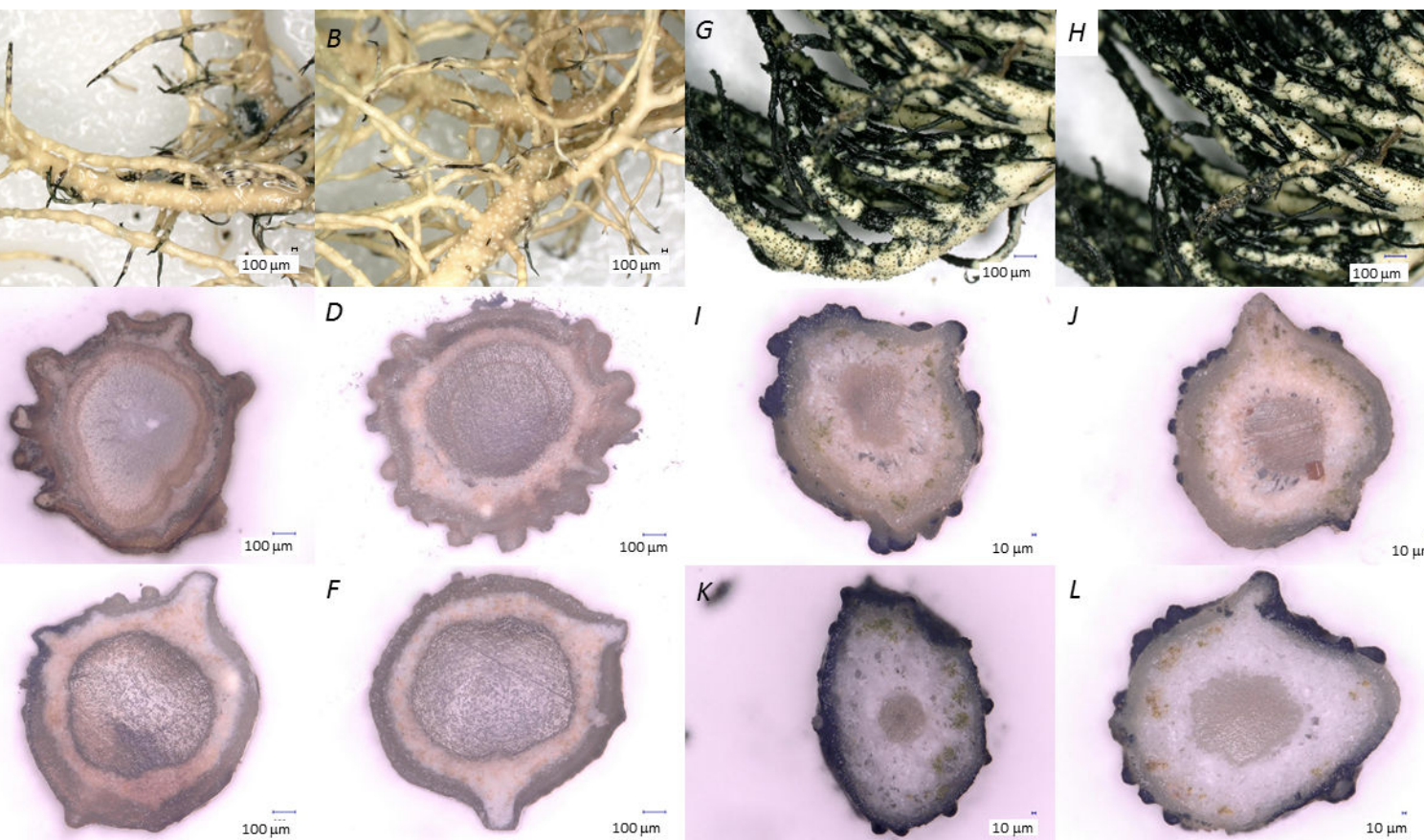

$F$
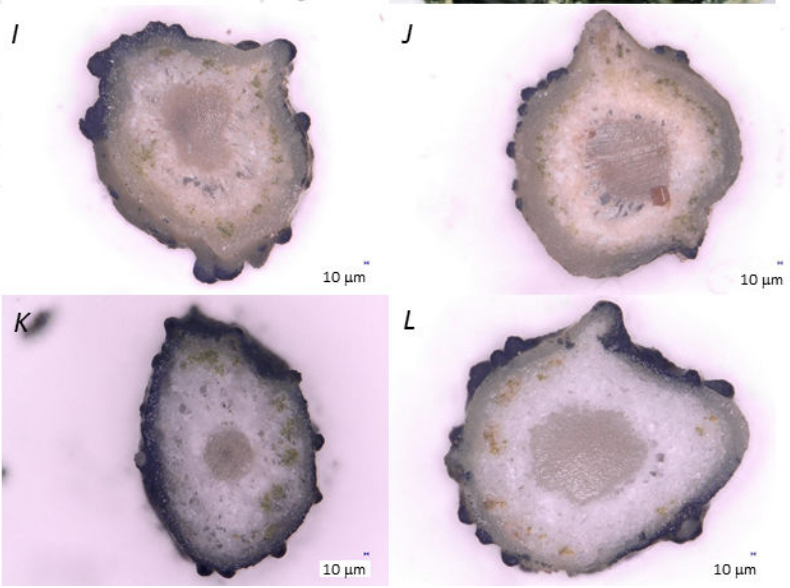

Fig. 2. Papillae distribution over a branching structure of Usnea aurantiaco-atra $(A, B)$, and Usnea sphacelata $(G, H)$. Selected crosssections showing papillae number and size in $U$. aurantiaco-atra $(C-F)$ and $U$. sphacelata $(I-L)$. The photos taken by a Keyence 500 digital microscope and its graphic software.

increase was found in the above-optimum temperature within the first 24 and $48 \mathrm{~h}$, followed by a decrease after $96 \mathrm{~h}$. At $1.5^{\circ} \mathrm{C}$, no change from control (i.e., before cultivation experiment) was found. Maximum Chl fluorescence signal $\left(\mathrm{F}_{\mathrm{M}}\right)$ showed a time-dependent decrease in high $\left(28^{\circ} \mathrm{C}\right)$ and low $\left(1.5^{\circ} \mathrm{C}\right)$ temperatures. Chl fluorescence signal at $\mathrm{P}$ point $\left(\mathrm{F}_{\mathrm{P}}\right)$ showed a time-dependent increase in optimum temperature $\left(15^{\circ} \mathrm{C}\right)$, and a decrease at high $\left(28^{\circ} \mathrm{C}\right)$ and low $\left(1.5^{\circ} \mathrm{C}\right)$ temperature.

\section{Discussion}

Thallus anatomy: Cross-sections of Usnea sphacelata and $U$. aurantiaco-atra revealed that the thickness of particular layers differed in separate thalli parts, i.e., basal, middle, and apex. Interspecific differences were apparent as well. Overall thallus morphology was classified according to Cao et al. (2018) for each species. Our data showed that $U$. aurantiaco-atra belonged to the morphological groups 1 and 2: 1 - thallus with apothecia without soredia, 2 - thallus with apothecia with soredia, while U. sphacelata fitted to the group 3 - thallus without apothecia and with soredia. For U. sphacelata, however, rare apothecia are reported by Walker (1985). U. aurantiaco-atra, on the other hand, has numerous apothecia, and soralia are either observed or missing (Seymour et al. 2007). The species, however, is found without soralia more frequently, similarly to the thalli examined in our study. The presence of papillae on the upper side of the cortex is typical for $U$. sphacelata. Only a limited number of papillae was observed in $U$. aurantiaco-atra. The species was typical by numerous secondary branches which were differentiated from papillae according to cross-sections as well (Fig. 2B-F).

The upper cortex averaged $9.1 \%$ of the cross-section diameter in U. sphacelata and $10.8 \%$ in U. aurantiacoatra (Fig. 3). The upper cortex consisted of dense, parallelarranged rows of thick-walled fungus cells. The upper cortex is considered a protective layer for lichens (He et al. 2012), in which a wide variety of phenolic secondary metabolites is localized. Among them, usnic acid is reported to be localized on the surface of the upper cortex of Usnea sp. (Gerlach et al. 2017). The amount of usnic acid, however, may differ within a season in Antarctica (Quilhot et al. 1991).

Relative area of cord: In the central part of thalli, an axis of the thallus (cord), is found, consisting of fibers longitudinally oriented and closely connected. The hyphae are formed by tightly ordered chondroid cells (see e.g., Tõrra and Randlane 2007). In our study, a wide range of relative area of the cord was found $(51.5,41.7$, and $19.9 \%$ for basal, middle, and apical parts of U. aurantiaco-atra, respectively, while $10.7,9.8$, and $6.9 \%$ for basal, middle, and apical parts of $U$. sphacelata, respectively). For the basal part of $U$. aurantiaco-atra, Seymour et al. (2007) reported 56 and $61 \%$ area of cord, respectively, which is well comparable to our data. Data for the middle and top of the thallus are missing. A more detailed analysis of the ratio of the central section (cord) of the thallus to the overall width of the thallus $U$. sphacelata allows comparison with the data published in the experimental study by Zvěřina 


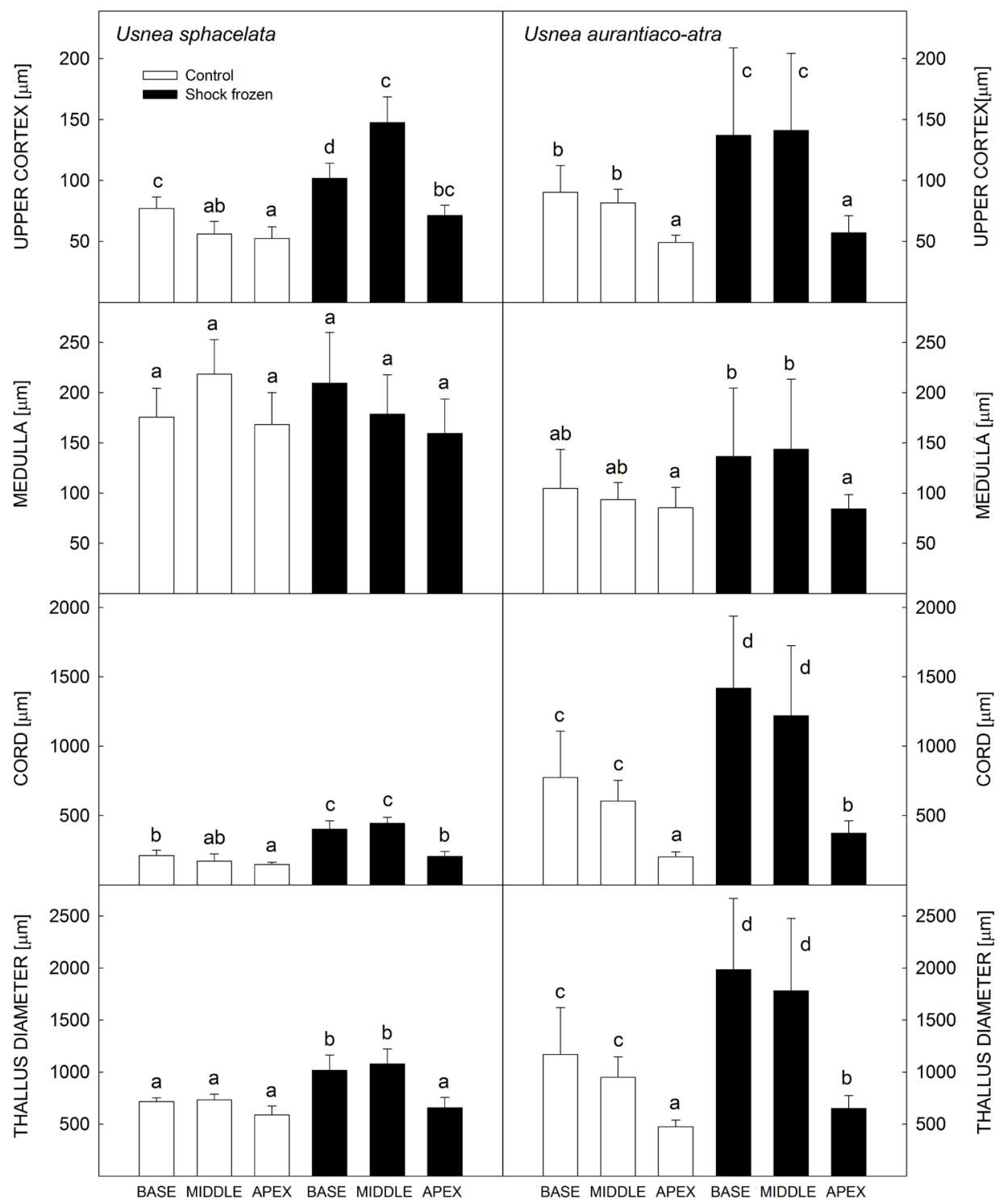

Fig. 3. Biometrical thalli parameters evaluated from crosssections of Usnea sphacelata and Usnea aurantiaco-atra: upper cortex thickness, medulla thickness, cord diameter, and thallus diameter. The data represent mean of 60 replicates \pm SD for particular parameters measured in untreated control and the thalli treated by shock freezing. Different letters show significant differences (ANOVA, Fisher's LDS test, $p<0.05)$.

et al. (2018), which recalculated the proportions of the basal - middle - apical part of $U$. sphacelata thallus as $48-28-11 \%$.

In other species of Usnea genus, the ratio evaluated for basal part tends to reach somewhat lower values: $41 \%$ (U. florida; data from the Department of Botany, University Hamburg), 38 and 44\% (U. intermedia and U. fulvoreagens; http://www.lichenes.de/), 44\% (U. longissima; Sanders and de los Ríos 2012). For Usnea lichens from tropical areas, which are characterized by long, pendulous thalli, the ratio of the central section (cord) area to the overall area of the cross-section of the thallus is often less than for lichens from polar regions. This is evidenced by the data published in Ohmura (2012), which, after calculating the ratio, gives a value of $45 \%$ for $U$. ceratina, $21 \%$ for $U$. bicolarata, and $32 \%$ for $U$. rubrotineta.

Apart from the differences found in the relative cord area for basal, middle, and apex part, one must consider also age-dependent differences related to the development of particular parts of the anatomical structure. It was shown by Ott (2004) that intrathalline anatomical differentiation starts in the early developmental stages of $U$. antarctica (form soredia). Partial components, i.e., the upper cortex, algal layer, medulla, and central axis (cord) can be easily distinguished. For 6-year-old $U$. antarctica thalli, the author reported central cord occupied most of the space inside such young thallus.

Rapid freezing resulted in statistically significant changes in some anatomical parameters. It might be attributed to the mechanisms of tissue injury caused by a fast cooling rate. In such a case, intracellular ice and extracellular ice crystals are formed (Ba et al. 2013), that cause mechanical damage to the cell membranes. Rapid freezing (immersion into liquid $\mathrm{N}$ ), however, does not lead to freezing-induced cellular dehydration, because extracellular ice formation is not, due to too short time, supported by water transport from the cells to extracellular spaces. Upper cortex thickness, thallus thickness, and cord diameter responded most sensitively in both species and increased after rapid freezing and melting. Such response 


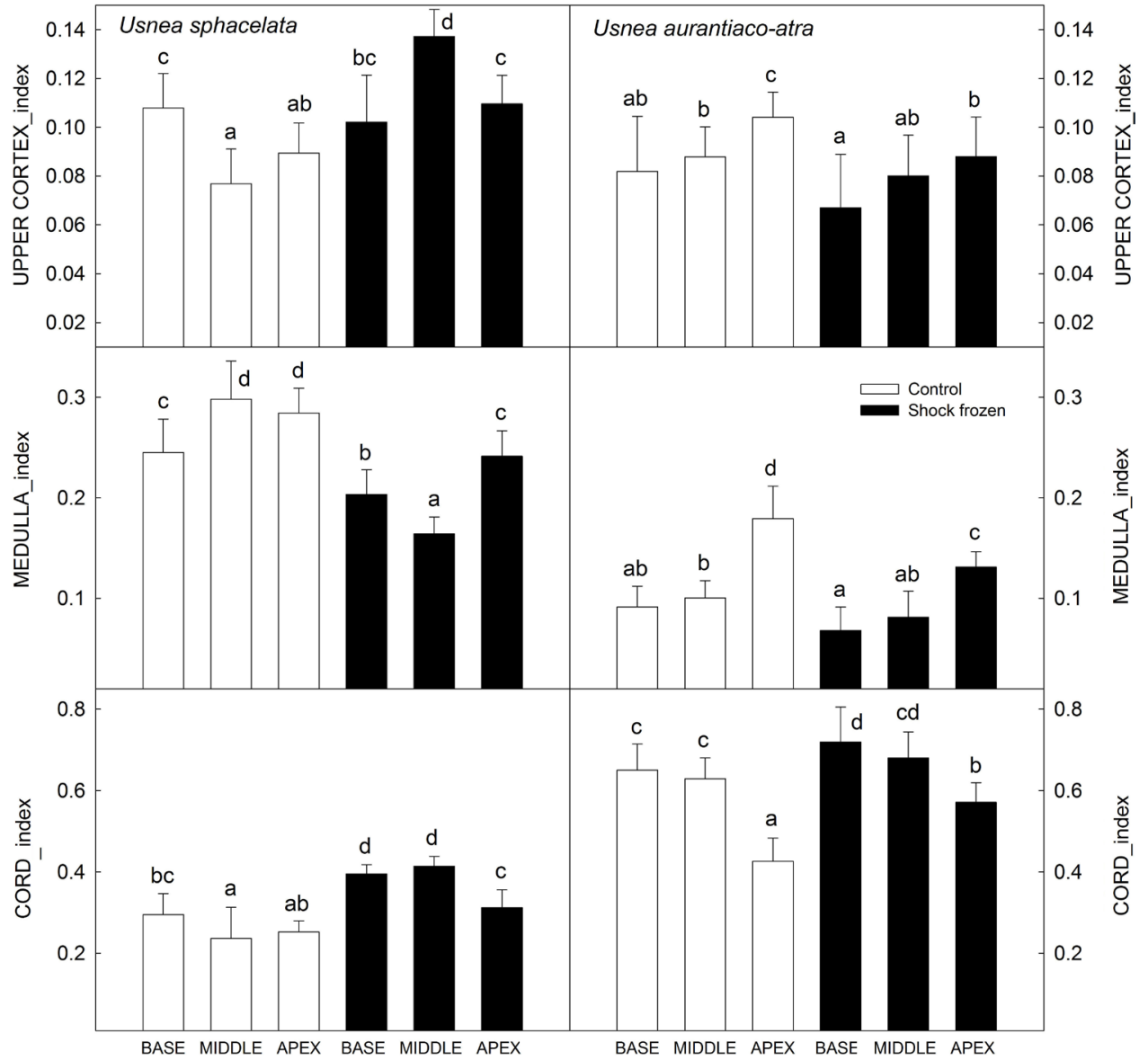

Fig. 4. Biometrical indices (relative to thallus diameter) evaluated for cross-sections of Usnea sphacelata and Usnea aurantiaco-atra: upper cortex thickness, medulla thickness, cord diameter, and thallus diameter. The data represent mean of three replicates \pm SD for particular parameters measured in untreated control and the thalli treated by shock freezing. Different letters show significant differences (ANOVA, Fisher's LSD test, $p<0.05)$.

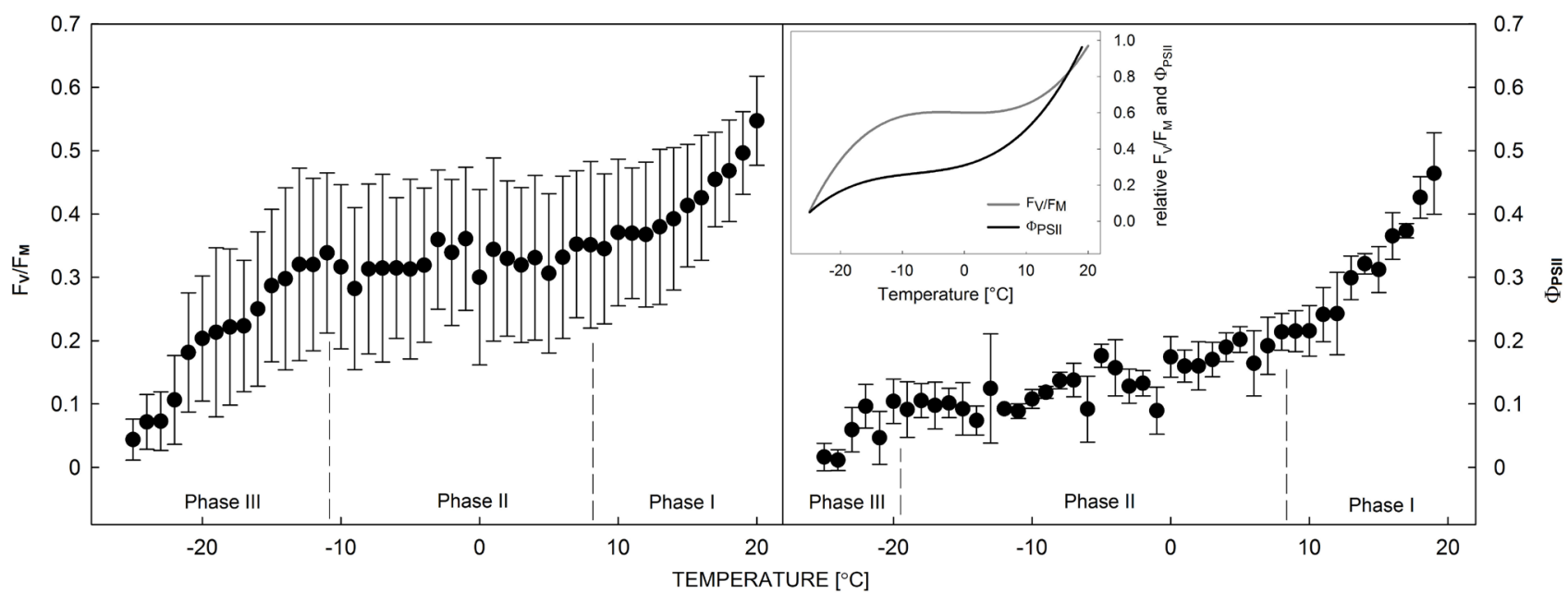

Fig. 5. Effect of linear cooling on chlorophyll fluorescence parameters. Left panel: $\mathrm{F}_{\mathrm{V}} / \mathrm{F}_{\mathrm{M}}$ - potential yield of photochemical processes of photosynthesis in photosystem II; right panel: $\Phi_{\mathrm{PSII}}-$ effective quantum yield of photochemical processes of photosynthesis in photosystem II of Trebouxia sp. The data points represent mean values of at least three replicates \pm SD for a class of $1^{\circ} \mathrm{C}$. The inset shows fitted curves for $\mathrm{F}_{\mathrm{V}} / \mathrm{F}_{\mathrm{M}}$ and $\Phi_{\mathrm{PSII}}$ as dependent on thallus temperature.

can be attributed to the volume growth of frozen water (compared to liquid) that irreversibly increased the size of the thallus structures typical by densely arranged hyphae. Medulla, typical by large intercellular spaces, did not show any freezing-induced increase in the size (thickness) in both species. Ice crystals formation in Antarctic lichens depends also on the size of intrathalline ice-nucleating particles. For $U$. aurantiaco-atra, different sizes of the particles may shift ice nucleation temperature from -8.3 to $-5.1^{\circ} \mathrm{C}$ (Worland et al. 1996). 


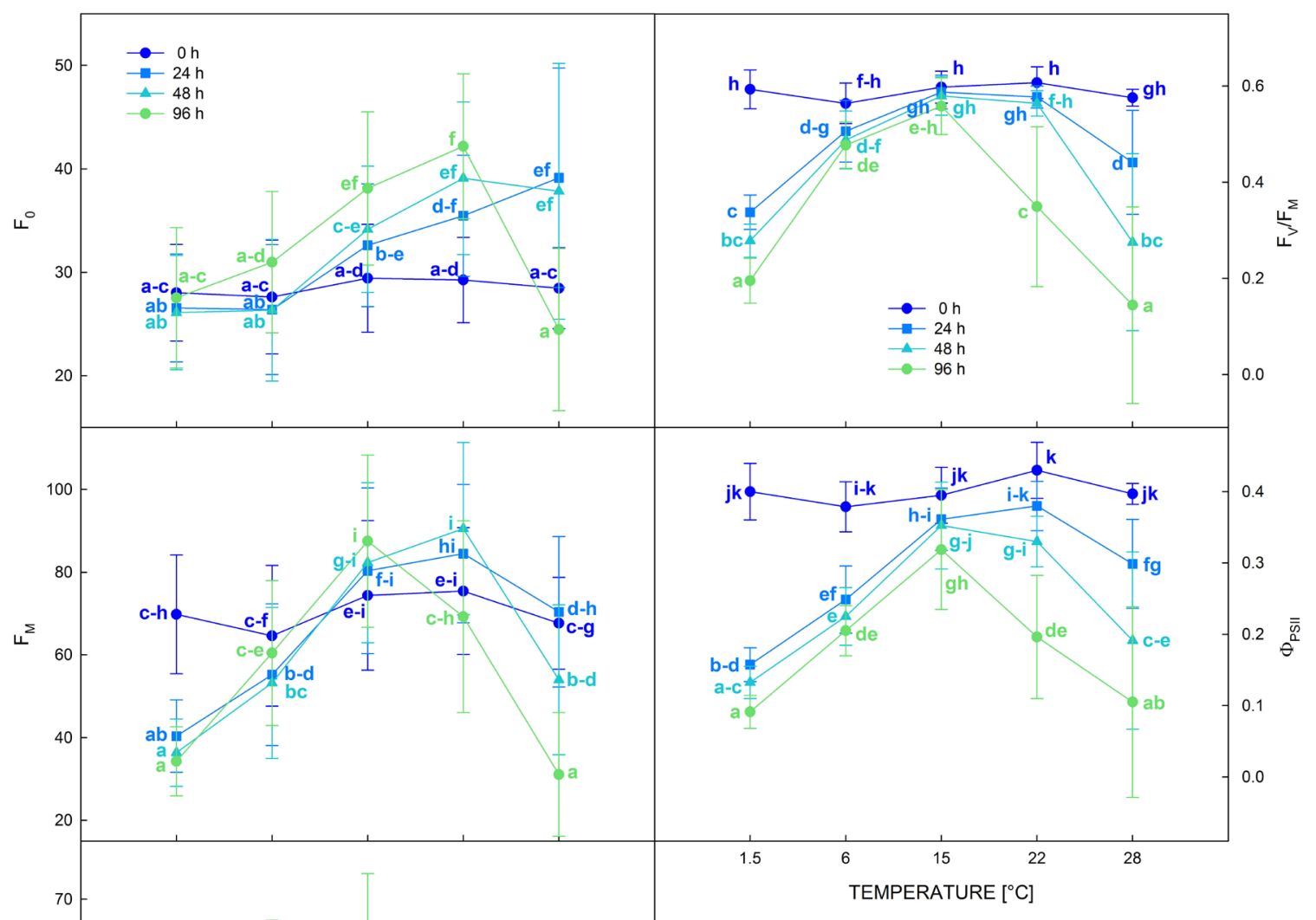

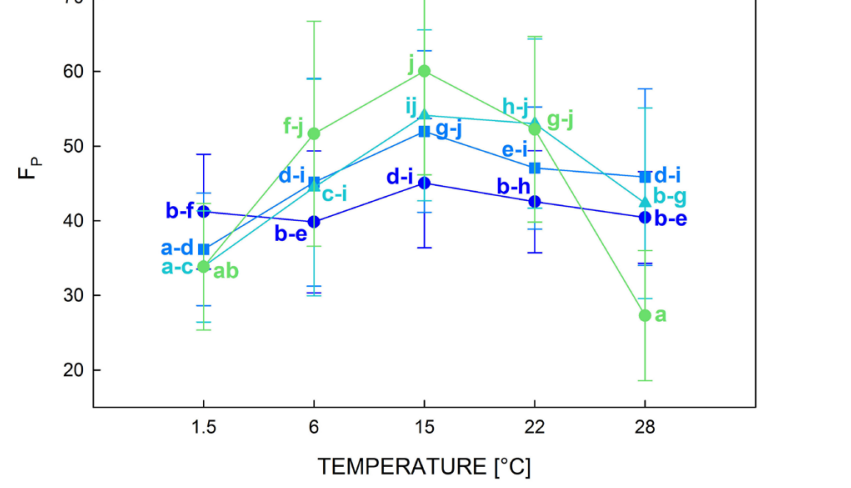

Effect of freezing on Chl fluorescence parameters: The polyphasic decrease of the maximum quantum yield $\left(\mathrm{F}_{\mathrm{V}} / \mathrm{F}_{\mathrm{M}}\right)$ of $T$. erici during linear cooling is comparable to the response of poikilohydric organisms, lichens (Hájek et al. 2016) and mosses (Folgar-Cameán and Barták 2019). The decrease in $\mathrm{F}_{\mathrm{V}} / \mathrm{F}_{\mathrm{M}}$ and $\Phi_{\mathrm{PSII}}$ with temperature decrease is associated with increased limitation of PSII functioning, photosynthetic linear electron flow, and utilization of ATP, NADPH in primary photosynthesis products formation (Genty et al. 1989). At sub-zero temperature, a significant decrease in $\mathrm{F}_{\mathrm{V}} / \mathrm{F}_{\mathrm{M}}$ at the accelerated rate occurred at $-12^{\circ} \mathrm{C}$. Such a response could be associated with the phenomenon of ice crystals formation (ice nucleation) as reported by Schroeter and Scheidegger (1995) and Harańczyk et al. (2003) for fully hydrated lichens exposed to freezing temperature. $\mathrm{F}_{\mathrm{V}} / \mathrm{F}_{\mathrm{M}}$ decrease is caused by a sub-zero temperature-induced decrease of absolute $F_{M}$ values simultaneously co-occurring increase in background fluorescence $\left(\mathrm{F}_{0}\right.$ relative to $\left.\mathrm{F}_{\mathrm{M}}\right)$ as shown earlier for lichens
Fig. 6. Temperature response curves of selected chlorophyll fluorescence parameters gained for Trebouxia sp. after different cultivation periods $(24,48$, and $96 \mathrm{~h})$. The data represent mean of three replicates \pm SD. Different letters show significant differences between the variants (ANOVA, Fisher's LSD test, $p<0.05) . \quad \mathrm{F}_{0}-$ background chlorophyll fluorescence; $\mathrm{F}_{\mathrm{M}}-$ maximum chlorophyll fluorescence reached after the application of a saturation pulse in dark-adapted state; $\mathrm{F}_{\mathrm{P}}$ - peak chlorophyll fluorescence reached after the continuous (actinic) light is switched on; $\mathrm{F}_{\mathrm{V}} / \mathrm{F}_{\mathrm{M}}$ - potential yield of photochemical processes of PSII; $\Phi_{\text {PSII }}$ - effective quantum yield of photochemical processes of PSII.

(Mishra et al. 2015) and vascular plants as well (Mishra et al. 2011). The critical temperature for $\mathrm{F}_{\mathrm{V}} / \mathrm{F}_{\mathrm{M}}$ and $\Phi_{\mathrm{PSII}}$ is similar, i.e. $-25^{\circ} \mathrm{C}$, for most lichens (Hájek et al. 2016). In general, the significant decrease in $\mathrm{F}_{\mathrm{V}} / \mathrm{F}_{\mathrm{M}}$ and $\Phi_{\mathrm{PSII}}$ values recorded in the cooling temperature ranged from $-12^{\circ} \mathrm{C}$ to $-25^{\circ} \mathrm{C}$ can be explained by the formation of crystallization cores and the formation of ice crystals, which takes place at nucleation temperature.

The results obtained in this experiment using the linear cooling method for T. erici algae are comparable to those obtained by Šabacká and Elster (2006), who investigated 15 species of filamentous cyanobacteria, predominantly of the genus Phormidium, and 9 species of unspecified green terrestrial algae. The authors evaluated the viability of algal cells exposed to various methods of cooling, including linear cooling. This characteristic is significantly higher for algal samples taken in continental Antarctica than in coastal Antarctica. These conclusions can also be supported by the results of an earlier study carried out on 
various algal species of the genus Trebouxia (Hájek et al. 2012), which reported a decrease in viability to $60-74 \%$ using a similar method of linear cooling. Besides, the reported decreases in $\mathrm{F}_{\mathrm{V}} / \mathrm{F}_{\mathrm{M}}$ and $\Phi_{\mathrm{PSII}}$ were species-specific in this work and differed between the T. asymmetrica, T. glomerata, and T. erici species studied.

The ability of Trebouxia sp. cells to maintain primary photosynthetic processes is related to the ability to form extracellular ice at sub-zero temperature, which is considered a protective mechanism (Moffett et al. 2015). Several phases of ice formation might be distinguished thanks to free and bound water molecules. The process is supported by the substances with nucleation activity, the presence of which has been proven for $U$. antarctica thalli (Harańczyk et al. 2006). The temperature of the ice nucleation is, however, species-specific. Moffett et al. (2015) determined the nucleation temperature for numerous lichen species from different regions of the Earth and reported $-6.5^{\circ} \mathrm{C}$ for Usnea. The value is slightly higher than that found for $T$. erici in our study $\left(-12^{\circ} \mathrm{C}\right.$, see Fig. 5). This difference can be explained by the fact that the nucleation temperature for the genus Usnea was measured on samples from England, while the alga T. erici used for our experiments was isolated from the Antarctic lichen $U$. antarctica. This is also consistent with data of Kvíderová et al. (2013) who reported the range of $-12^{\circ} \mathrm{C}$ to $-16^{\circ} \mathrm{C}$ for Trebouxia sp.

Cultivation optimum for Trebouxia sp. assessed by $\mathrm{Chl}$ fluorescence: The temperature optima for $\mathrm{F}_{\mathrm{V}} / \mathrm{F}_{\mathrm{M}}$ and $\Phi_{\mathrm{PSII}}$ found at $15^{\circ} \mathrm{C}$ are well comparable to an earlier study of Bayer and Alba (2017) who reported the range of $10-20^{\circ} \mathrm{C}$ for several $\mathrm{Chl}$ fluorescence parameters related to $T$. erici PSII activity. The optima, however, cannot be related to the whole photosynthetic pathway because no biochemical processes were studied in this experiment. Domaschke et al. (2013) measured photosynthetic and growth optima for Trebouxia sp. Their oximetry data suggest that the temperature optimum of photosynthesis could be as low as $11^{\circ} \mathrm{C}$ if measured on Trebouxia sp. isolated from lichens from polar regions. Another study in T. erici (Sehnal et al. 2014) reports optimum temperature higher than $12^{\circ} \mathrm{C}$ based on $\mathrm{F}_{\mathrm{V}} / \mathrm{F}_{\mathrm{M}}$, pigments, and biomass production. The ability of Antarctic algae to grow at a higher than optimum temperature is in agreement with the findings of Seaburg et al. (1981).

For growth rate and biomass production of Antarctic terrestrial microalgae evaluated by optical density (OD), the range $6-14^{\circ} \mathrm{C}$ is reported as the optimum growth temperature (Chlorella sp., Stichococcus sp.; Teoh et al. 2004). For Trebouxia sp., similar OD-based growth rates are reported for 10 and $15^{\circ} \mathrm{C}$ during short-term cultivation (16 d) by Balarinová et al. (2014). With prolonged cultivation (16-30 d), however, the authors report a faster growth rate at $10^{\circ} \mathrm{C}$.

Conclusions: Comparative anatomic study of two species collected from Antarctica (Usnea aurantiaco-atra, King George Island; U. sphacelata, James Ross Island) revealed that the two species differed in biometrical parameters derived from cross-sections of their thalli. U. sphacelata had similar values of the relative thickness of cortex (0.080-0.110, relative to diameter) as $U$. aurantiacoatra (0.085-0.130). Other parameters showed speciesspecificity. The relative thickness of medulla was found higher in U. sphacelata than U. aurantiaco-atra. The cord formed about two times larger part of the overall crosssection area in $U$. aurantiaco-atra than in $U$. sphacelata in basal, middle, and apex parts of the thallus. Since rapid freezing of wet lichen thalli accompanied by the formation of intra- and extracellular ice crystals occur in maritime Antarctica quite frequently, we studied the sensitivity of anatomical parameters to rapid freezing. In the laboratorybased experiment, rapid freezing in liquid nitrogen, followed by gradual thawing led to an increase in thallus diameter, upper cortex thickness, and cord diameter, more apparently in $U$. aurantiaco-atra than $U$. sphacelata. Photosynthetic responses to sub-zero temperature were evaluated for symbiotic alga Trebouxia sp. exposed to linear cooling from physiological $\left(20^{\circ} \mathrm{C}\right)$ to sub-zero temperature $\left(-30^{\circ} \mathrm{C}\right)$. The cooling-induced decrease in potential $\left(\mathrm{F}_{\mathrm{V}} / \mathrm{F}_{\mathrm{M}}\right)$ and effective quantum yield of PSII $\left(\Phi_{\text {PSII }}\right)$ were triphasic showing a fast-slow-fast decline of the two Chl fluorescence parameters with temperature fall. Strong limitation of PSII primary photosynthetic processes occurred at the temperature below $-10^{\circ} \mathrm{C}$, which might be attributed to ice formation. The critical temperature, at which full inhibition of $F_{V} / F_{M}$ and $\Phi_{\text {PSII }}$ was found, reached $-25^{\circ} \mathrm{C}$. Despite such cryo-resistance of primary photochemical processes of photosynthesis in Trebouxia sp. had their temperature optimum at $15^{\circ} \mathrm{C}$ in a shortterm $(96 \mathrm{~h})$ experiment. It revealed that optimum growth temperature was $15^{\circ} \mathrm{C}$ for both species, and potential $\left(\mathrm{F}_{\mathrm{V}} / \mathrm{F}_{\mathrm{M}}\right)$ and actual $\left(\Phi_{\mathrm{PSII}}\right)$ primary photosynthetic processes declined in a curvilinear manner with temperature fall from 20 to $-30^{\circ} \mathrm{C}$ (critical temperature).

\section{References}

Ba Y., Mao Y., Galdino L., Günsen Z: Effects of a type I antifreeze protein (AFP) on the melting of frozen AFP and $\mathrm{AFP}+$ solute aqueous solutions studied by NMR microimaging experiment. - J Biol Phys. 39: 131-144, 2013.

Balarinová K., Barták M., Hazdrová J. et al:: Changes in photosynthesis, pigment composition and glutathione contents in two Antarctic lichens during a light stress and recovery. Photosynthetica 52: 538-547, 2014.

Bayer T., Alba N.V.: Temperature optima for growth and photosynthetic processes in Trebouxia erici isolated from an Antarctic lichen and cultivated in a temperature gradient. Czech Polar Rep. 7: 34-44, 2017.

Bednaříková M., Folgar-Cameán Y., Kučerová Z. et al.: Analysis of K- and L-band appearance in OJIPs in Antarctic lichens in low and high temperature. - Photosynthetica 58: 646-656, 2020a.

Bednař́ková M., Váczi P., Lazár D., Barták M.: Photosynthetic performance of Antarctic lichen Dermatocarpon polyphyllizum when affected by desiccation and low temperatures. Photosynth. Res. 145: 159-177, 2020b.

Cao S., Zhang J., Zheng H. et al.: Photosynthetic performance in Antarctic lichens with different growth forms reflect the diversity of lichenized algal adaptation to microhabitats. - 
Pol. Polar Res. 36: 175-188, 2015.

Cao S., Zheng H., Cao Y. et al.: Morphological differentiation and phylogenetic homogeneity in Usnea aurantiaco-atra reveal the complexity of lichen symbiosis. - Pol. Polar Res. 39: 313-328, 2018.

Casanova-Katny A., Torres-Mellado G.A., Eppley S.M.: Reproductive output of mosses under experimental warming on Fildes Peninsula, King George Island, maritime Antarctica. Rev. Chil. Hist. Nat. 89: 13, 2016.

Cho S.M., Lee H., Hong S.G., Lee J.: Study of ecophysiological responses of the Antarctic fruticose lichen Cladonia borealis using the PAM fluorescence system under natural and laboratory conditions. - Plants-Basel 9: 85, 2020.

Colesie C., Büdel B., Hurry V., Green T.G.A.: Can Antarctic lichens acclimatize to changes in temperature? - Glob. Change Biol. 24: 1123-1135, 2018.

Domaschke S., Vivas M., Sancho L.G., Printzen C.: Ecophysiology and genetic structure of polar versus temperate populations of the lichen Cetraria aculeata. - Oecologia 173: 699-709, 2013.

Eriksson A.: Water storage in the lichen genus Usnea in Sweden and Norway. Can morphological and water storage traits explain the distribution and ecology of epiphytic species? Thesis. Pp. 35. Umeå, Sweden 2016.

Eriksson A., Gauslaa Y., Palmqvist K. et al.: Morphology drives water storage traits in the globally widespread lichen genus Usnea. - Fungal Ecol. 35: 51-61, 2018.

Folgar-Cameán Y., Barták M.: Evaluation of photosynthetic processes in Antarctic mosses and lichens exposed to controlled rate cooling: Species-specific responses. - Czech Polar Rep. 9: 114-124, 2019.

Genty B., Briantais J.M., Baker N.R.: The relationship between the quantum yield of photosynthetic electron transport and quenching of chlorophyll fluorescence. - BBA-Gen. Subjects 990: 87-92, 1989.

Gerlach A.C.L., Clerc P., Borges Da Silveira R.: Taxonomy of the corticolous, shrubby, esorediate, neotropical species of Usnea Adans. (Parmeliaceae) with an emphasis on southern Brazil. - Lichenologist 49: 199-238, 2017.

Hájek J., Barták M., Gloser J.: Effects of thallus temperature and hydration on photosynthetic parameters of Cetraria islandica from contrasting habitats. - Photosynthetica 39: 427-435, 2001.

Hájek J., Barták M., Hazdrová J., Forbelská M.: Sensitivity of photosynthetic processes to freezing temperature in extremophilic lichens evaluated by linear cooling and chlorophyll fluorescence. - Cryobiology 73: 329-334, 2016.

Hájek J., Váczi P., Barták M.: Photosynthetic electron transport at low temperatures in the green algal foliose lichens Lasallia pustulata and Umbilicaria hirsuta affected by manipulated levels of ribitol. - Photosynthetica 47: 199-205, 2009.

Hájek J., Váczi P., Barták M., Jahnová L.: Interspecific differences in cryoresistance of lichen symbiotic algae of genus Trebouxia assessed by cell viability and chlorophyll fluorescence. - Cryobiology 64: 215-222, 2012.

Harańczyk H., Grandjean J., Olech M., Michalik M.: Freezing of water bound in lichen thallus as observed by ${ }^{1} \mathrm{H}$ NMR. II. Freezing protection mechanisms in a cosmopolitan lichen Cladonia mitis and in Antarctic lichen species at different hydration levels. - Colloid. Surface. B 28: 251-260, 2003.

Harańczyk H., Pietrzyk A., Leja A., Olech M.A.: Bound water structure on the surfaces of Usnea antarctica as observed by NMR and sorption isotherm. - Acta Phys. Pol. A 109: 411416, 2006.

He Y.Z., Tang H., Zhang Z.G.: Ultramicromorphological observation of Usnea longissimi Ach. - Afr. J. Biotechnol. 11:
7102-7108, 2012.

Jonsson Čabrajić A.V., Lidén M., Lundmark T. et al.: Modelling hydration and photosystem II activation in relation to in situ rain and humidity patterns: a tool to compare performance of rare and generalist epiphytic lichens. - Plant Cell Environ. 33: 840-850, 2010.

Kappen L., Sommerkorn M., Schroeter B.: Carbon acquisition and water relations of lichens in polar regions - Potentials and limitations. - Lichenologist 27: 531-545, 1995.

Kvíderová J., Hájek J., Worland R.M.: The ice nucleation activity of extremophilic alga. - CryoLetters 34: 137-148, 2013.

Laguna-Defior C., Pintado A., Green T.G.A. et al.: Distributional and ecophysiological study on the Antarctic lichens species pair Usnea antarctica/Usnea aurantiaco-atra. - Polar Biol. 39: 1183-1195, 2016.

Marečková M., Barták M.: Effects of short-term low temperature stress on chlorophyll fluorescence transients in Antarctic lichen species. - Czech Polar Rep. 6: 54-65, 2016.

Mark K., Saag L., Leavitt S.D. et al.: Evaluation of traditionally circumscribed species of the lichen-forming genus Usnea, section Usnea (Parmeliaceae, Ascomycota) using a six-locus dataset. - Org. Divers. Evol. 16: 497-524, 2016.

Mishra A., Hájek J., Tuháčková T. et al.: Features of chlorophyll fluorescence transients can be used to investigate low temperature induced effects on photosystem II of algal lichens from polar regions. - Czech Polar Rep. 5: 99-111, 2015.

Mishra A., Mishra K.B., Höermiller I.I. et al.: Chlorophyll fluorescence emission as a reporter on cold tolerance in Arabidopsis thaliana accessions. - Plant Signal. Behav. 6: 301-310, 2011.

Moffett B.F., Getti G., Henderson-Begg S.K., Hill T.C.J.: Ubiquity of ice nucleation in lichen - possible atmospheric implications. - Lindbergia 38: 39-43, 2015.

Ohmura Y.: A synopsis of the lichen genus Usnea (Parmeliaceae, Ascomycota) in Taiwan. - Mem. Natl. Mus. Nat. Sci. Tokyo 48: 91-137, 2012.

Orekhova A., Barták M., Hájek J.: Post rapid freezing growth of Antarctic strain of Heterococcus sp. monitored by cell viability and chlorophyll fluorescence. - Cryobiology 85: 39-46, 2018.

Ott S.: Early stages of development in Usnea antarctica Du Rietz in the South Shetland Islands, northern maritime Antarctica. Lichenologist 36: 413-423, 2004.

Øvstedal D.O., Lewis Smith R.I.: Lichens of Antarctica and South Georgia. A Guide to Their Identification and Ecology. Pp. 411. Cambridge University Press, Cambridge 2001.

Quilhot W., Peña W., Flores E. et al.: Temporal variation in usnic acid concentration in Usnea aurantiaco-atra (Jaq.) Bory. Serie Científica, Instituto Antárctico Chileno 41. Pp. 99-106. Instituto Antárctico Chileno, Chile 1991.

Randlane T., Tõrra T., Saag A., Saag L.: Key to European Usnea species. - In: Thell A., Seaward M.R.D., Feuerer T. (ed.): Bibliotheca Lichenologica 100. The Diversity of Lichenology: Jubilee Volume. Pp. 419-462, J. Cramer, Berlin 2009.

Roháček K., Soukupová J., Barták M.: Chlorophyll fluorescence: A wonderful tool to study plant physiology and plant stress. In: Schoefs B. (ed.): Plant Cell Compartments - Selected Topics. Pp. 41-104. Research Signpost, India 2008.

Ruiz-Fernández J., Oliva M., García-Hernández C.: Topographic and geomorphologic controls on the distribution of vegetation formations in Elephant Point (Livingston Island, Maritime Antarctica). - Sci. Total Environ. 587-588: 340-349, 2017.

Sanders W.B., de los Ríos A.: Development of thallus axes in Usnea longissima (Parmeliaceae, Ascomycota), a fruticose lichen showing diffuse growth. - Am. J. Bot. 99: 998-1009, 2012. 
Sancho L.G., Pintado A., Navarro F. et al.: Recent warming and cooling in the Antarctic peninsula region has rapid and large effects on lichen vegetation. - Sci. Rep.-UK 7: 5689, 2017.

Seaburg K.G., Parker B.C, Wharton R.A., Simmons G.M.: Temperature-growth responses of algal isolates from Antarctic oases. - J. Phycol. 17: 353-360, 1981.

Sehnal L., Váczi P., Barták M.: Effect of temperature and increased concentration of $\mathrm{CO}_{2}$ on growth and photosynthetic activity of polar alga Trebouxia sp. - Czech Polar Rep. 4: 47-56, 2014

Seymour F.A., Crittenden P.D., Wirtz N. et al.: Phylogenetic and morphological analysis of Antarctic lichen-forming Usnea species in the group Neuropogon. - Antarct. Sci. 19: 71-82, 2007.

Schroeter B., Scheidegger C.: Water relations in lichens at subzero temperatures: Structural changes and carbon dioxide exchange in the lichen Umbilicaria aprina from continental Antarctica. - New Phytol. 131: 273-285, 1995.

Šabacká M., Elster J.: Response of cyanobacteria and algae from Antarctic wetland habitats to freezing and desiccation stress. Polar Biol. 30: 31-37, 2006.

ten Veldhuis M.-C., Ananyev G., Dismukes G.C.: Symbiosis extended: exchange of photosynthetic $\mathrm{O}_{2}$ and fungal-respired $\mathrm{CO}_{2}$ mutually power metabolism of lichen symbionts. Photosynth. Res. 143: 287-299, 2020.
Teoh M.-L., Chu W.-L., Marchant H., Phang S.-M.: Influence of culture temperature on the growth, biochemical composition and fatty acid profiles of six Antarctic microalgae. - J. Appl. Phycol. 16: 421-430, 2004.

Tõrra T., Randlane T.: The lichen genus Usnea (lichenized Ascomycetes, Parmeliaceae) in Estonia with a key to the species in the Baltic countries. - Lichenologist 39: 415-438, 2007.

Truong C., Rodriguez J., Clerc P.: Pendulous Usnea species (Parmeliaceae, lichenized Ascomycota) in tropical south America and the Galapagos. - Lichenologist 45: 505-543, 2013.

van Kooten O., Snell J.F.H.: The use of chlorophyll fluorescence nomenclature in plant stress physiology. - Photosynth. Res. 25: 147-150, 1990.

Walker F.J.: The Lichen Genus Usnea subgenus Neuropogon. Bulletin of the British Museum (Natural History). Pp. 130. British Museum, London 1985. ISBN-13: 978-0565080044.

Worland M.R., Block W., Oldale H.: Ice nucleation activity in biological material with examples from antarctic plants. CryoLetters 17: 31-38, 1996.

Zvěřina O., Coufalík P., Barták M. et al.: The contents and distributions of cadmium, mercury, and lead in Usnea antarctica lichens from Solorina Valley, James Ross Island (Antarctica). - Environ. Monit. Assess. 190: 13, 2018.

(C) The authors. This is an open access article distributed under the terms of the Creative Commons BY-NC-ND Licence. 